Gut, 1972, 13, 986-995

\title{
Ultrastructural findings in idiopathic recurrent cholestasis
}

\author{
D. HOPWOOD ${ }^{1}$, A. E. READ, AND R. WILLIAMS \\ From the Department of Pathology, University of Nottingham, the Medical Unit, University of Bristol, and \\ the Liver Unit, King's College Hospital, London
}

SUMMARY Needle liver biopsies of patients with idiopathic recurrent cholestasis were studied by light and electron microscopy. Many hepatocytes showed non-specific damage to their organelles. Crystalloids were found both in the cytoplasm and within mitochondria in one patient. The microscopic and clinical findings were interpreted as being in favour of primary hepatocyte injury.

There are now a number of clinical and pathological reports of idiopathic or benign recurrent cholestasis. The cardinal features of this condition are repeated episodes of jaundice, pruritus, bilirubinuria, and weight loss, but without pain or progressive liver damage (Summerskill and Walshe, 1959). Either sex may be affected. The mechanisms of the recurrent icterus remain obscure, but it is accompanied by raised serum transaminase and the serum alkaline phosphatase is not as high as in purely cholestatic conditions. The serum cholesterol is usually normal even in prolonged attacks and this, together with the reduced maximum and storage capacity of bromsulphthalein as well as the impaired transport maximum (Biempica, Gutstein, and Arias, 1967), led Williams, Cartter, Sherlock, Scheuer, and Hill (1964) to prove that diffuse hepatocellular changes are present during the acute step. Some of the affected individuals have been related (Biempica et al, 1967; Ozsoylu Kocak, 1971; Rotthauwe, Beseler, and Kowalewski, 1969), but Williams et al (1964) have argued that the disease is probably of environmental origin rather than constitutional.

Four of these earlier papers have contained reports on the ultrastructure of the liver in the disease during both jaundice and remission. Summerskill (1965), Dickson, Fletcher, and Summerskill (1965) and Da Silva and Brito (1966) described round to oval vacuoles close to the cell membrane which, they claimed, were specific for benign recurrent chole-

${ }^{1}$ Present address: Department of Pathology, The University of Dundee.

Received for publication 4 October 1972. stasis. Biempica et al (1967), however, were unable to find these structures in their material. The other features they reported were not specific. The present report describes the ultrastructure of bile ductules in benign recurrent cholestasis as well as that of hepatocytes and littoral cells.

\section{Clinical Material}

\section{PATIENT D}

This patient was one of the two cases first described with this condition (Summerskill and Walshe, 1959) and had had 23 attacks over an 18-year period at the time of the study by Williams et al (1964) of the functional and pathological lesions found in idiopathic recurrent cholestasis. Since this time he has continued to have attacks of varying severity despite, at times, long-term maintenance therapy with prednisone and more recently phenobarbitone. The longest interval free of jaundice has been 21 months. This was immediately before the attack in which the biopsy described in this paper was taken (January, 1970). The jaundice had started four weeks previously following an influenza-like illness. When admitted to hospital the liver was enlarged $2 \mathrm{~cm}$ below the costal margin; the patient was moderately jaundiced with numerous scratch marks over the skin. Serum bilirubin was $4.2 \mathrm{mg} / 100 \mathrm{ml}$, alkaline phosphatase 22 King-Armstrong units, serum asparate aminotransferase $35 \mathrm{IU} / \mathrm{hr}$, serum albumin $3 \mathrm{~g} / 100 \mathrm{ml}$. He was treated with cholestyramine with symptomatic improvement and slow recovery over the subsequent months.

Intensive investigations in the past have included 
four laparatomies which have shown no evidence of extrahepatic obstruction or hepatic cirrhosis. Investigation of the BSP relative storage capacity and secretory transport maximum in the acute stage of previous attacks in this patient have shown a marked and proportionate reduction in both storage capacity and transport maximum. Improvement in both parameters occurred with clinical and biochemical recovery. The improvement in processes responsible for uptake and storage of dye by the liver as well as those concerned in its reaction in the bile are indicative of diffuse hepatocellular damage for which other functional criteria have been reported (Williams et al, 1964) as well as the pathological changes described in this paper.

PATIENT J.P.

He is now aged 45 years. In 1961 he suffered epigastric pain and mild jaundice with pruritis.

He was admitted to St. Mary's Hospital, where jaundice gradually faded and where an intravenous cholangiogram was normal and a liver biopsy showed centrilobular bile stasis.

Further episodes of jaundice occurred in 1969 and 1970.

In 1970 he was referred to the Bristol Royal Infirmary.

There is no significant past history, except one of asthma and no important family history.

Investigations in Bristol showed an icteric man with many scratch marks and the liver enlarged to three finger breadths. The liver function tests showed bilirubin 4.5 and a raised alkaline phosphatase 16 units. Enzymes and prothrombin time were normal. A Rose Bengal scan showed that the bile ducts were at least partially patent and a liver biopsy showed centrilobular cholestasis.

He was sent for laparotomy when no obstruction was found in the biliary tree and the diagnosis was considered to be recurrent cholestasis.

He has since remained well.

\section{Methods}

Percutaneous needle liver biopsies were obtained from the two patients D and J.P. Part of the material was processed for electron microscopy. This was fixed in $4 \%$ glutaraldehyde buffered to $p \mathrm{H} 7 \cdot 2$ with $0.2 \mathrm{M}$ cacodylate postosmicated, and embedded in Araldite. Thin sections were cut with an LKB ultratome, stained with uranyl acetate and lead citrate (Watson, 1958; Reynolds, 1963), and examined with a Phillips 300 electron microscope.

For light microscopy the tissue was fixed in $4 \%$ formaldehyde, embedded in paraffin wax, and stained with haematoxylin and eosin.
Morphological Observations

\section{LIGHT MICROSCOPY}

\section{Patient D}

Light microscopy of paraffin sections revealed a retained pattern. There was a mild increase in lymphocytes and fibroblasts in the portal tracts which showed an increase in fibrous tissue. Hepatic venous radicles showed some fibrosis. The hepatocyte plates were mostly 2 cells wide (Fig. 1). The hepatocytes were pallid away from peribiliary zones towards the hepatic venous radicles (Fig. 2). Bile pigment precipitates predominated towards the central vein area but some were found in cells up to the portal tracts. Littoral cells were prominent, especially in regions where pigment precipitates were present, where many contained pigment material.

Patient J. P.

A retained pattern was found in the formaldehyde-

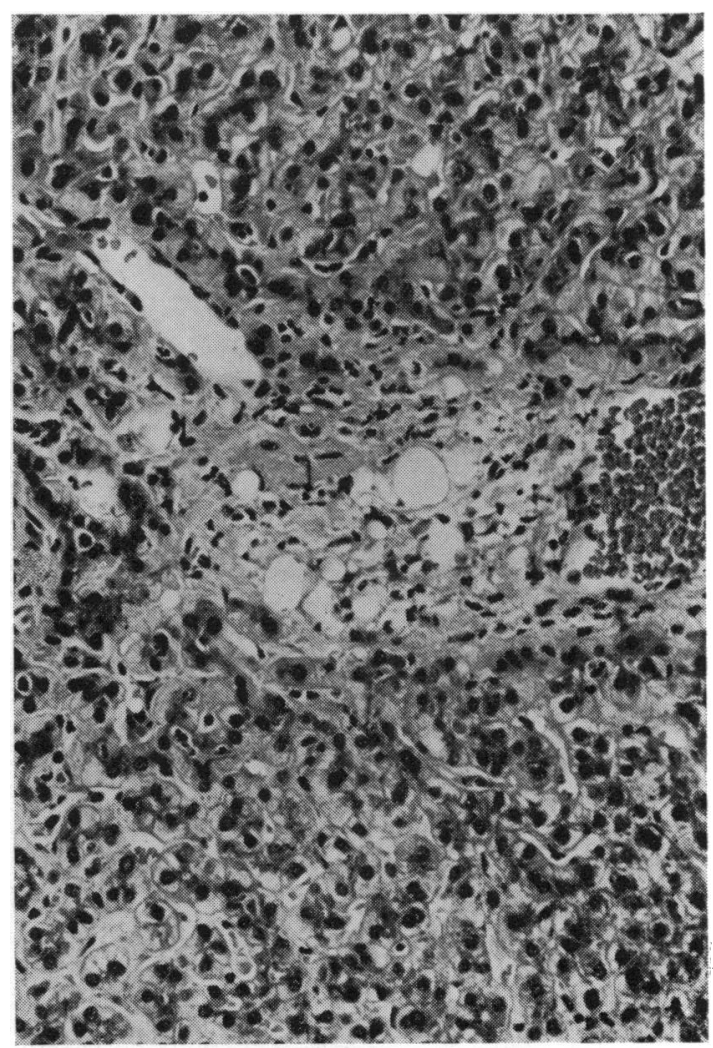

Fig. 1 Patient D: hepatocyte plates mostly 2 cells wide. Cytoplasmic pallor away from peribiliary area. Bile thrombi visible. $\times 315$. 


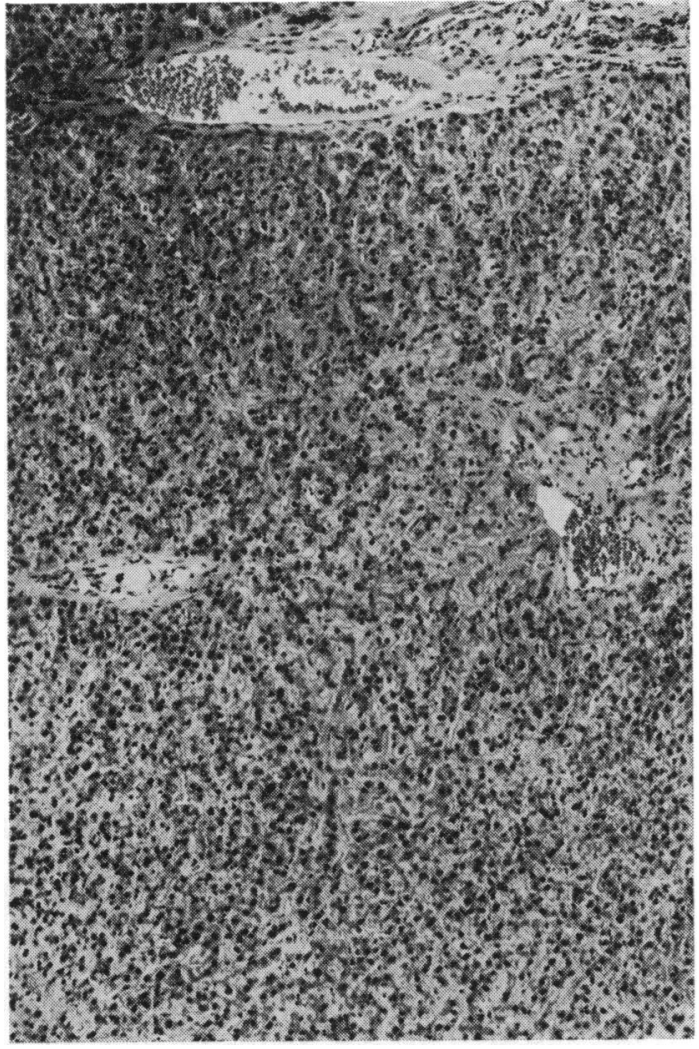

fixed specimen. The portal tracts were infiltrated with lymphocytes, macrophages, some eosinophils, and a sprinkling of polymorphonuclear leucocytes. There was no ductal or ductular proliferation nor portal oedema. Parenchymal plates were thickened and 2 cells thick in parts, but there were moderate numbers which were 1 cell thick near hepatic venous radicles. Hepatocytes were pale except in the pericanalicular regions. There were abundant bile pigment precipitates, in the canaliculi within the littoral cells, and as coarse granules in the hepatocytes. The pigment deposits were more abundant towards the hepatic venous radicles. The littoral cells were prominent near pigment precipitates.

\section{Electron Microscopic Findings}

\section{HEPATOCYTES}

The nuclei, nucleoli, internal dense lamella, nuclear membrane, and pores appeared normal. Some bile canaliculi were dilated to a variable extent. These showed sparse microvilli, some of which were greatly enlarged in diameter. Surrounding the canaliculi there was a cuff of cytoplasm with moderate electron density (Fig. 3). Higher magnifi-

Fig. 2 Patient D: hepatocytes pallid round venous radicles and away from peribiliary zones. Bile thrombi visible and increase in number of Kupffer cells. $\times 126$.

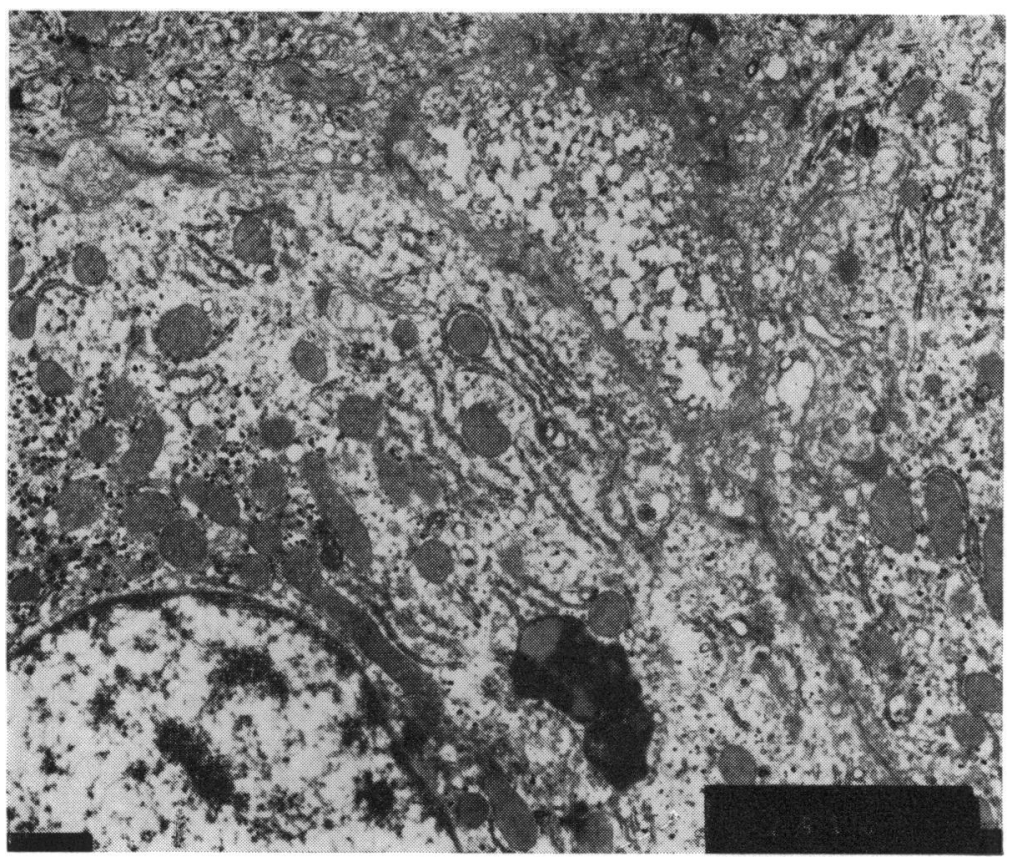

Fig. 3 Three hepatocytes with three bile canaliculi, that on the right appears normal, those on the left are dilated and contain various debris. Pericanalicular cuff around dilated canaliculus. Cytoplasm contains normal organelles and a residual body. $\times 6000$ 
cations failed to reveal any underlying (Fig. 4) structure other than a mesh of filaments. Bile canaliculi, from the same patient, which were not dilated did not show this cuff so well developed. The canaliculi contain various types of material. There were some small vesicles (2-400 ̊̊U diameter), some finely granular material, and electron-clear areas and membrane whorls. The cell membranes bordering the bile canaliculi were held together by desmosomes. Some cell membranes ran straight (Fig. 5) and others showed interdigitations (Fig. 5). About some cell membranes there was a zone 500-600 $\AA U$ in breadth which was not only devoid of organelles, but also showed a condensed material (Fig. 5). This was not present uniformly. Regular microvilli lined the space of Disse.

The mitochondria in general appeared normal in number and included granules. Occasionally cristae were curved. There were stacks of rough endoplasmic reticulum in most cells (Figs. 4,5 ) but in others the cisternae were dilated. The cisternae contained moderately electron-dense material. The smooth endoplasmic reticulum was associated with the glycogen areas. Golgi vesicles were seen in most cells. Some of these appeared empty except for a few slightly electron-dense granules the size of ribosomes (Figs. 6). Others contained larger electron dense material (Fig. 6). Most cells contained lysosomes, some of which were near the bile canaliculi. A few peroxysomes were seen. Some cells contained large residual bodies (Fig. 3). Glycogen was abundant and in rosette form (Fig. 5). Lipid droplets were encountered.

There is evidence of cellular damage. In some parts of the biopsies, groups of cells show dilated rough endoplasmic reticulum although the fixation is good. Membrane whorls (Figs. 4, 5, 7) of varying size were seen in many cells and residual bodies were abundant in others. The membrane structures were sometimes associated with slits in the cytoplasm. The biopsy

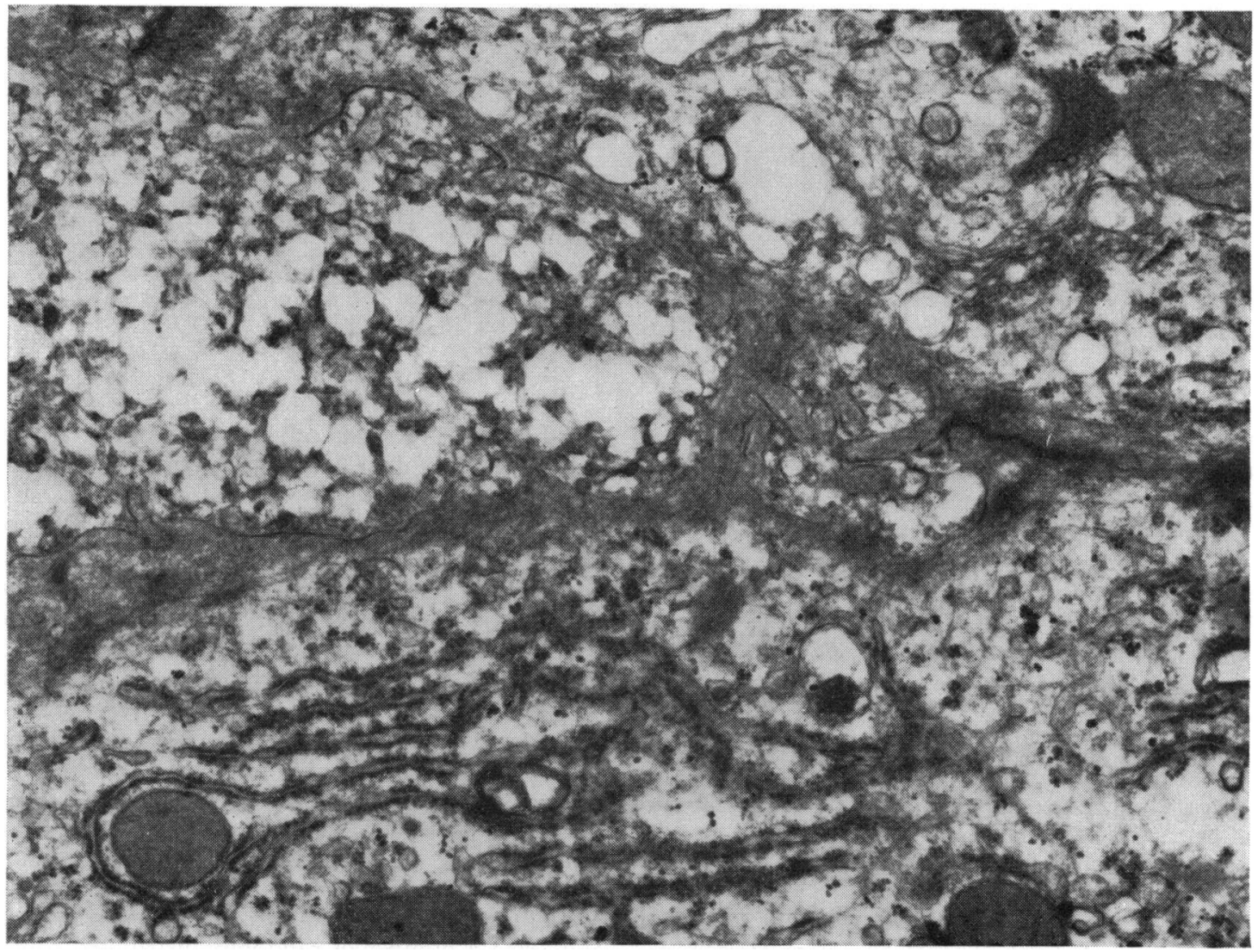

Fig. 4 Higher magnification of dilated bile canaliculus. The fibrillar nature of the cuff can be seen. The canaliculus contains amorphous material and small circular profiles. Reduced number of microvilli. $\times 21000$. 


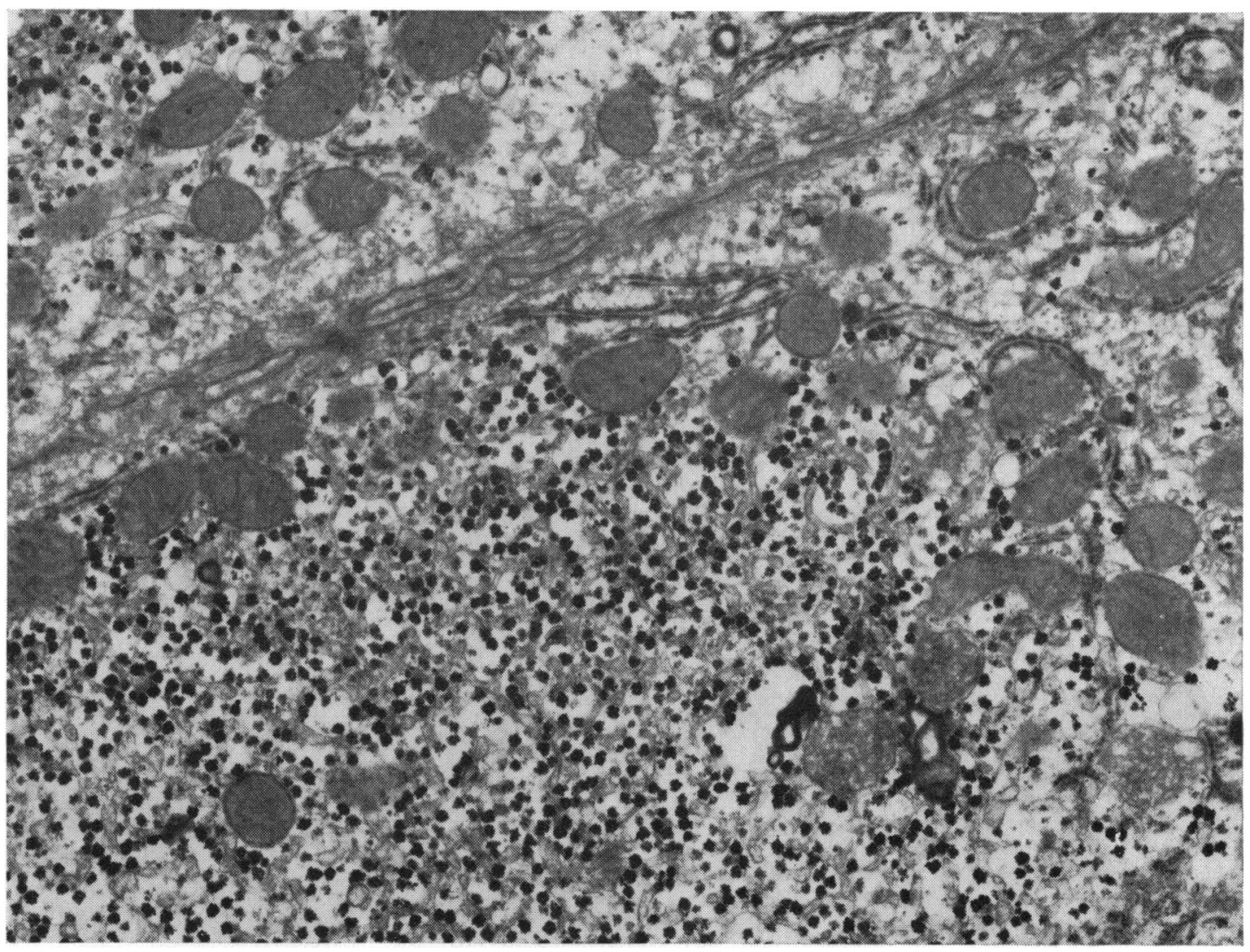

Fig. 5 Two hepatocytes. Cell membrane shows regions of interdigitations. Organelles absent from regions adjacent to cell membranes. Some membrane whorls present with glycogen rosettes. $\times 21000$.

from D. showed crystalloids within mitochondria (Fig. 8). The angles between the long axis of the crystalloid and the cristae varied between 103 and $130^{\circ}$. There were also numerous crystalloids free in the cytoplasm. These took two forms, either parallel arrays of dentate material (Fig. 8) or a lattice (Fig. 9). This last was composed of either filaments or particles packed in two parallel arrays at an angle of $124^{\circ}$. Several of these crystalloids were $1-2 \mu$ diameter, but were not seen under the light microscope. Lattice defects were seen. Some cells contained droplets bounded by a membrane (Fig. 10). In form and contents these are similar to those found after partial hepatectomy in rats.

\section{BILE DUCTULES}

The bile ductule was composed of four epithelial cells surrounded by a single basement membrane. The lumen appeared duplicated, the two components separated by a bridge of tissue divided by the plasma membranes of opposite cells. A junctional complex was present on these adjacent plasma membranes. This may merely represent a diverticulum or a projection into a single duct. The luminal surfaces of all the cells had microvilli, some of which appeared oedematous and lacking in central fibres. One area appeared relatively devoid of microvilli. The lumina contained a few small particles less than $100 \AA \AA U$ diameter, and a single membrane whorl. No cilia were seen. The lateral surfaces of the cells showed complex interdigitations near the lumen and again towards the basement membrane. The intervening region was straight. Junctional complexes were present centrally and about the bile canaliculi. No obvious pinocytotic vesicles were seen (Fig. 11).

The nuclei, internal dense lamellae, nuclear pores, and membranes were normal. The cytoplasm contained a number of randomly distributed round to oval mitochondria. Some of these contained vacuoles and membrane whorls as well as cristae. 


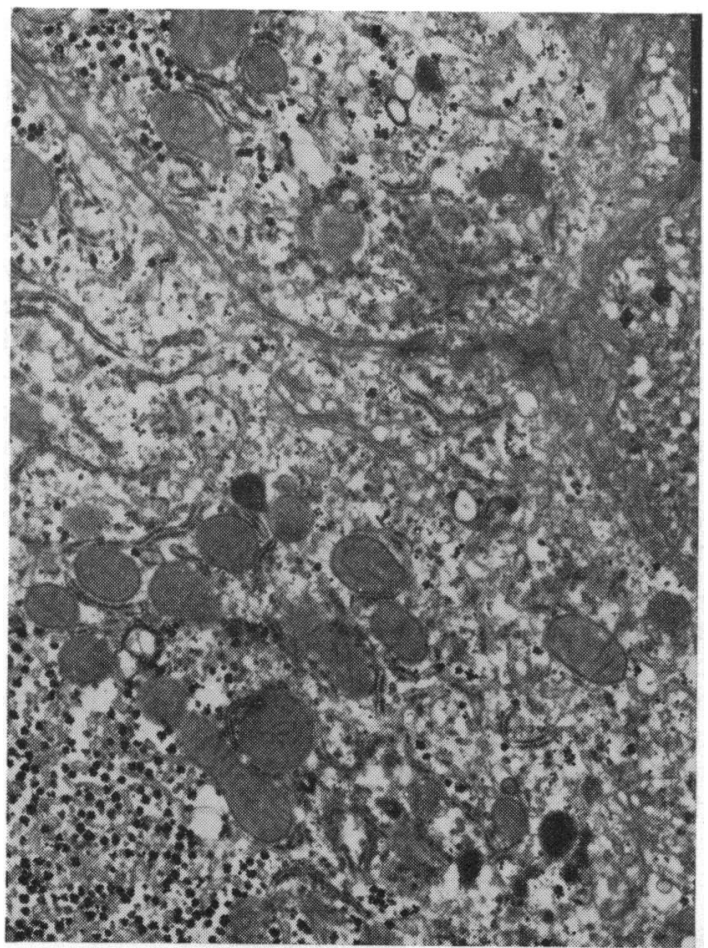

Fig. 6

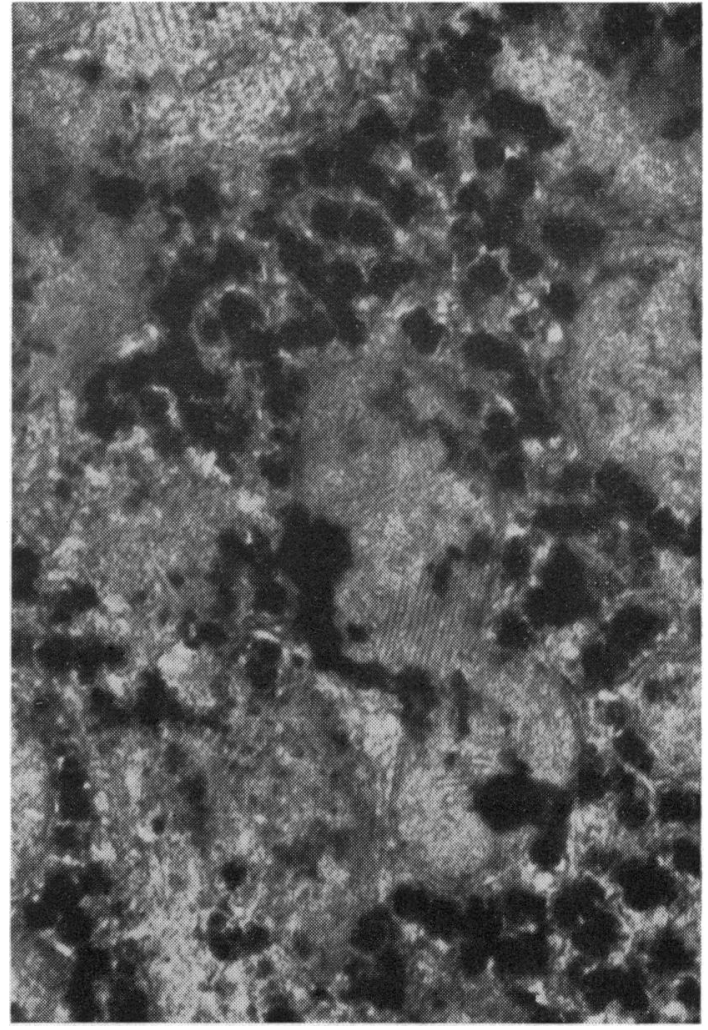

Fig. 8

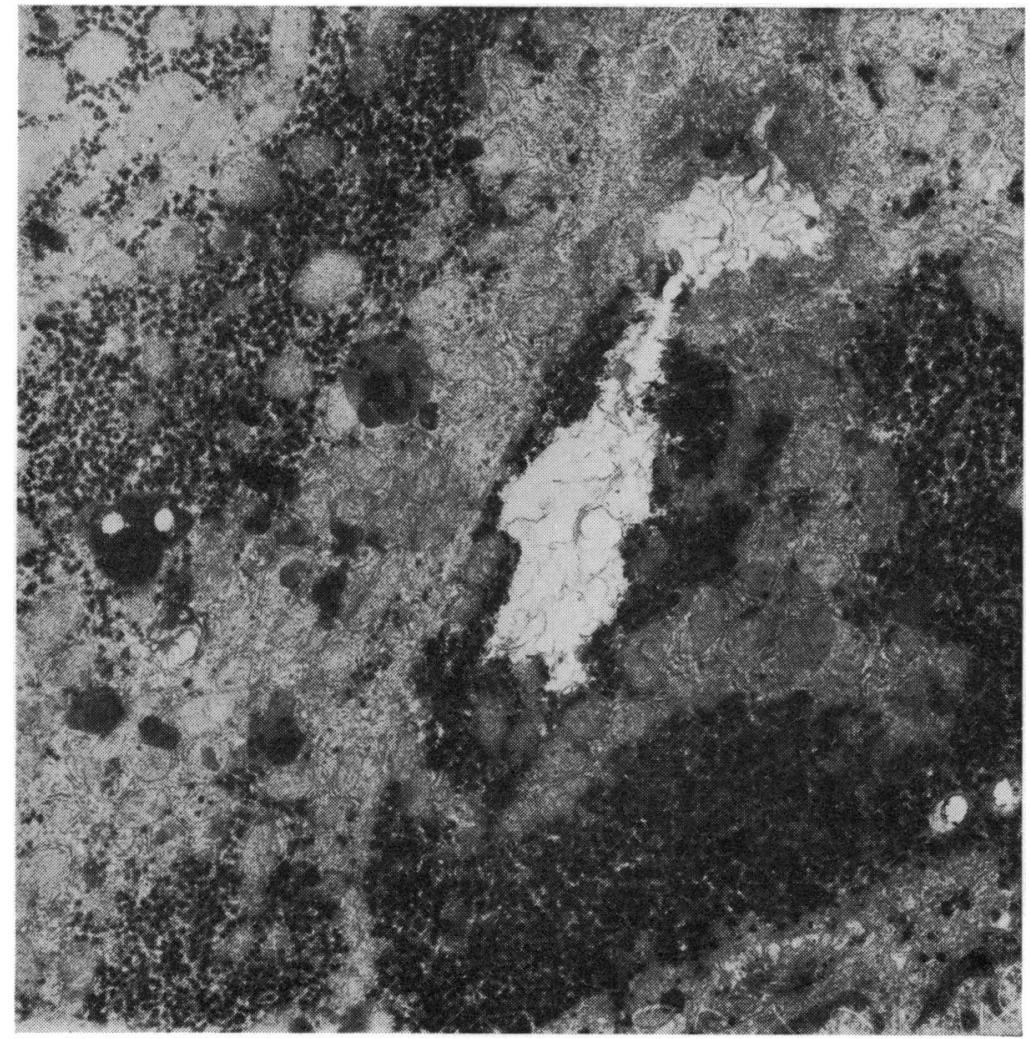

Fig. 6 Two hepatocytes. Golgi apparatus contains particulate material similar to that contained in cisternae of endoplasmic reticulum. Some Golgi vesicles apparently empty. $\times 21000$.

Fig. 7 Hepatocyte with slit in cytoplasm containing membranous whorls. $\times 30000$.

Fig. 8 Mitochondria from hepatocytes containing crystalloids. Dentate crystalloidin cytoplasm. $\times 30000$. 
There are a few cisternae of rough and smooth endoplasmic reticulum and free ribosomes. Each cell contained one or two lysosomes. There were also some vesicles with electron-lucent centres. The epithelial cells also contained some fibrils apparently randomly orientated, diameter 50-100 $\AA \mathrm{U}$, without periodicity (Fig. 12).

\section{KUPFFER CELLS}

Kupffer cells showed a moderate number of lysosomes in their cytoplasm.

\section{Discussion}

The light microscopy in the present cases of idiopathic recurrent cholestasis showed a severe cholestasis without coexistent inflammatory infiltrate in the portal regions. The pericanalicular haematoxophilia which was noted did not apparently have a counterpart at the ultrastructural level (Fig. 3). This may be due to sampling error.
In the present ultrastructural investigations of benign recurrent cholestasis, some observations are in common with the previous reports and others are new. Some of the earlier work, however, relied on osmium tetroxide fixation and methacrylate embedding. All previous investigaters of this lesion by electron microscopy have described dilated bile canaliculi, with a reduced number of microvilli and containing bile pigment and other debris (Summerskill, 1965; Dickson et al, 1965; Da Silva et al, 1966; Biempica et al, 1967; Tanikawa, 1968). Tanikawa (1968) also pointed out the cytoplasmic band or cuff related to the distended bile canaliculi. All these were found in the present patients. In the present study, some normal bile canaliculi were found, sometimes adjacent to dilated ones. This occurrence of dilated bile canaliculi adjacent to apparently normal ones has been described before in extrahepatic biliary obstruction (Popper and Schaffner, 1970). All of these findings on the bile canaliculi have been described in other forms of cholestasis.

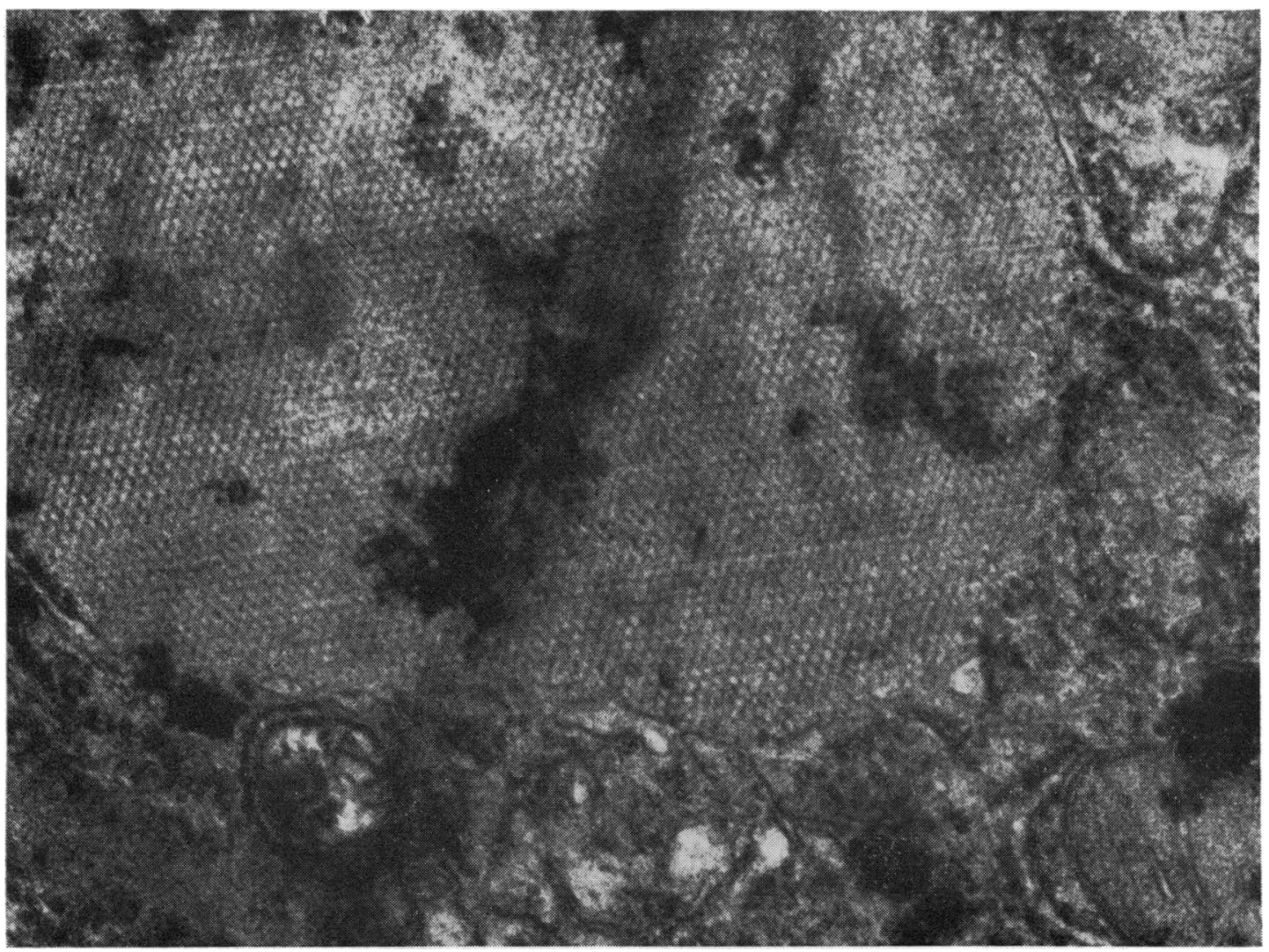

Fig. 9 Crystalloid in hepatocyte cytoplasm. $\times 40000$. 


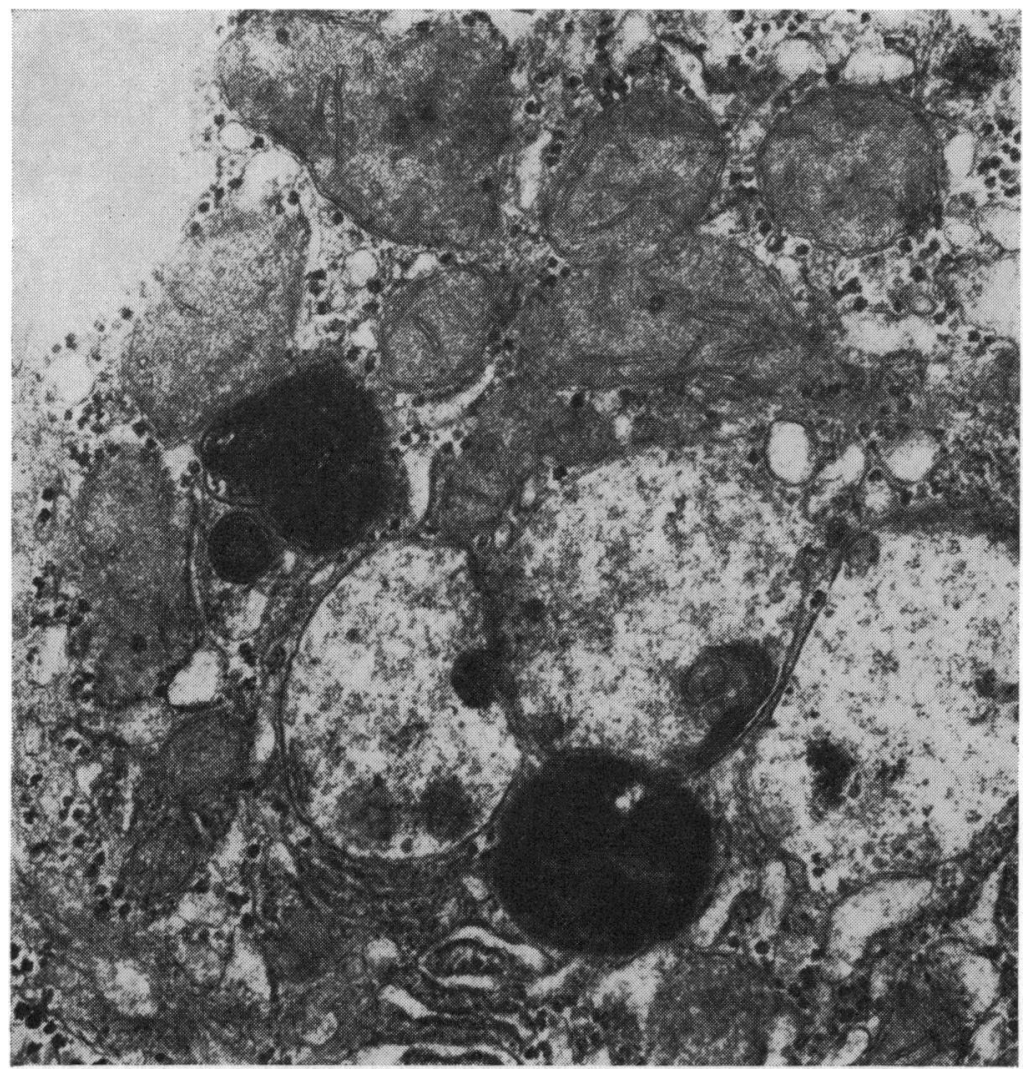

Fig. 10 Portion of

hepatocyte with three pale droplets one of which contains parallel membrane profiles. $\times 30000$.

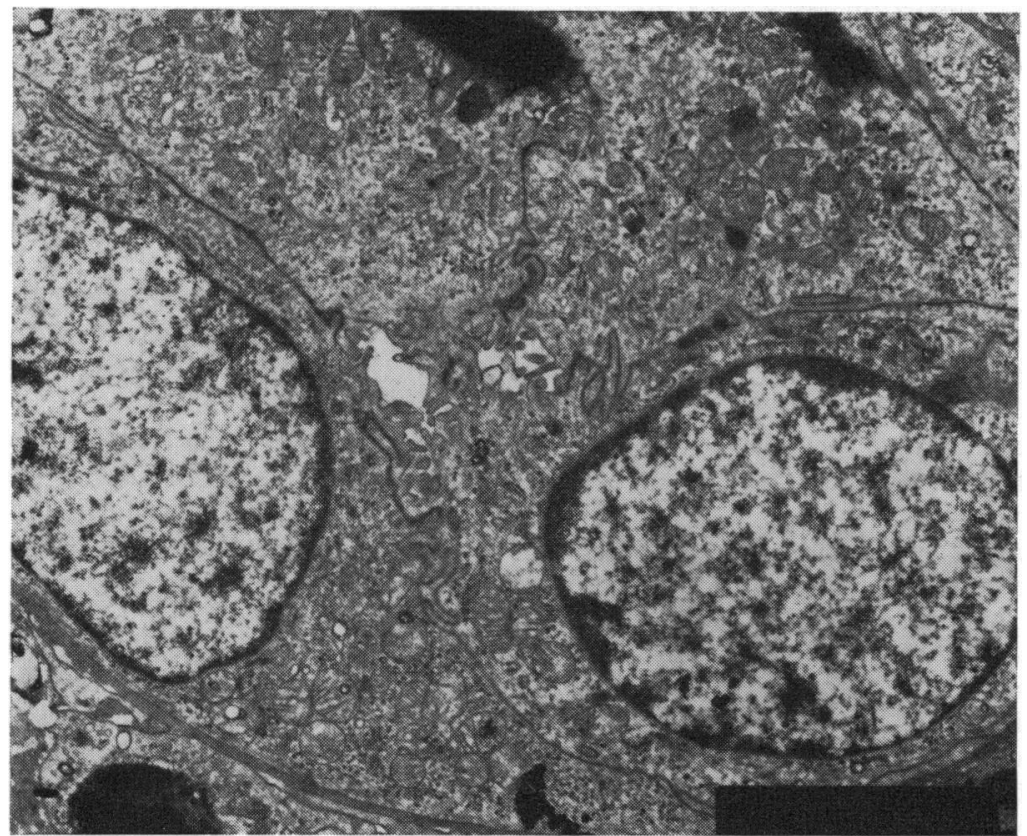

Fig. 11 Bile ductule surrounded by basement membrane. Two lumina near centre and one towards bottom of the micrograph. One lumen contains debris. $\times 4000$. 


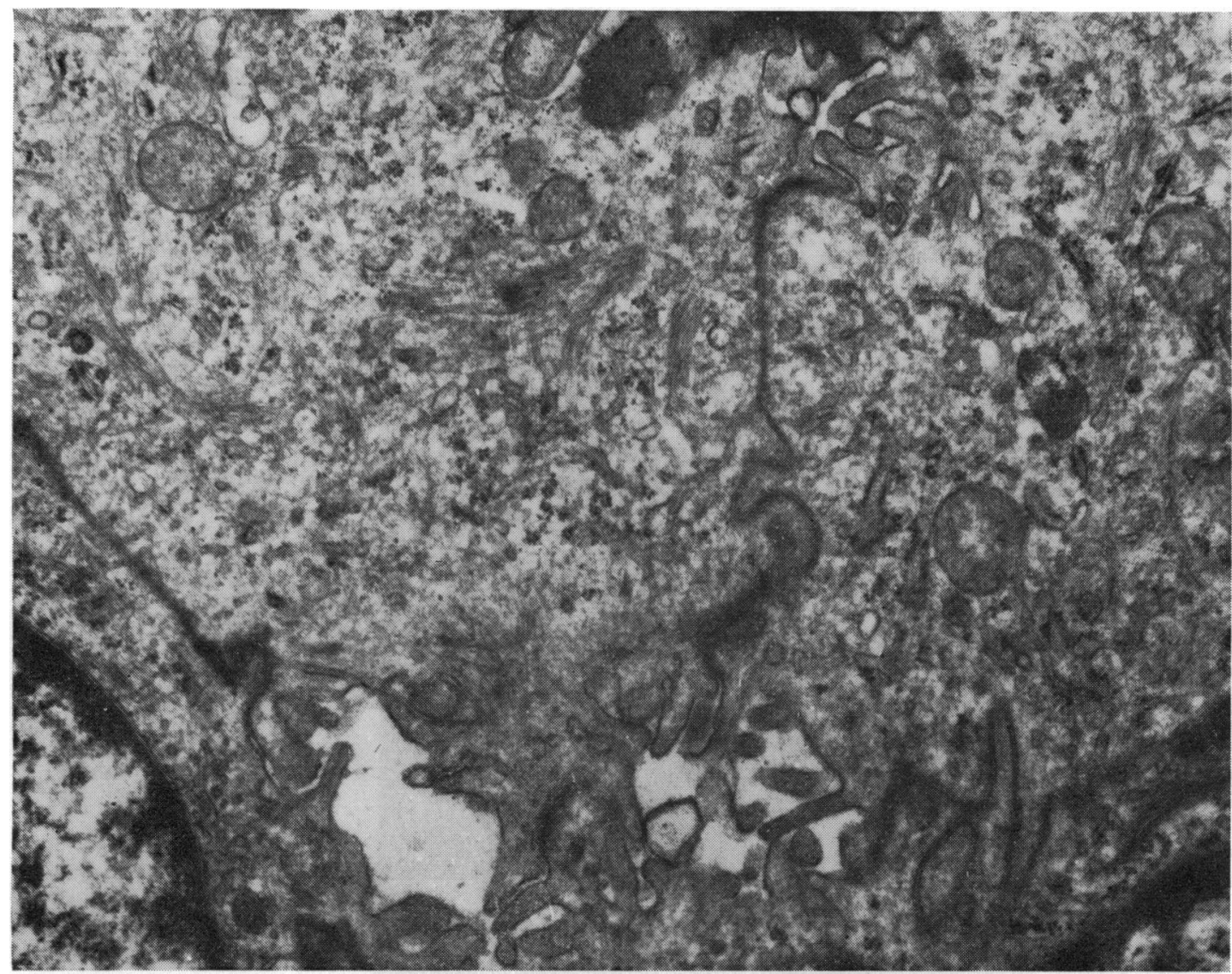

Fig. 12 Higher magnification of ductule cells. Tonofibrils clearly visible in cytoplasm. $\times 20000$.

Summerskill (1965), Dickson et al (1965), and Da Silva and Brito (1966) described vesicles, 1-5 $\mu$ diameter, containing material of moderate electron density in hepatocytes of benign recurrent cholestasis, which they thought were characteristic. These were not found in the present material, nor by Biempica et al (1967). Some droplets were seen in the present study whose ultrastructure is similar to that of the droplets appearing in regenerating rat liver (Pfeifer and Bannasch, 1968). These may represent a response to hepatocellular injury.

There is evidence in the biopsies of damage to many of the hepatocytes. Some cells show dilated, rough endoplasmic reticulum, membrane whorls, autophagic vacuoles, and numerous dense bodies.

The changes in bile ductules in intrahepatic cholestasis have been described by Sasaki, Schaffner, and Popper (1967). The most outstanding features were the loss of microvilli and the presence of bile in the cytoplasm. Neither of these was found, nor any of the other stigmata. The ductules found in the present cases more closely resembled the normal structure. The ductule cells in the present material showed fibrils in the cytoplasm. These were not found by Sasaki et al (1967) although they have been described previously in normal canine ductules (Schaffner and Popper, 1961) and in the ductules in patients with biliary cirrhosis (Tanikawa, 1968).

Crystalloids were found within mitochondria and free in the cytoplasm of liver cells in one of the biopsies (D). Intramitochondrial crystalloids have been described in normal human liver biopsies and in pathological biopsies from a large number of conditions (for reviews see Spycher and Rüttner, 1968, and Shiraki and Neustein, 1971), including cholestasis (Jézéque, 1959; Fahrländer, Huber, and Gloor, 1964). Their most frequent occurrence is in congenital dyserythropoietic anaemia where $30 \%$ of the mitochondria contain inclusions (Hug, Wong, and Lampkin, 1972). The crystalloids formed a well 
defined system of filaments with orthorhombic packing with angles of about $108^{\circ}$ and about $72^{\circ}$. The filaments formed a regular geometrical relationship to the cristae of $130^{\circ}$ in some mitochondria. In the present study the angles formed between the filaments varied between 100 and $130^{\circ}$. The significance of these structures is uncertain. They occur in normal tissue, in a variety of diseased ones, and are sensitive to oxygen tension. They may represent either a normal structure or a non-specific mitochondrial response to injury.

Cytoplasmic inclusions in human liver cells, on the other hand, are relatively rare. Sternlieb, Berger, Biempica, Quintana, and Hodge (1971) pointed out that only a dozen or so cases have been reported previously. Although the crystalloids occur in normal individuals they have also been described in chronic hyperbilirubinaemia (Feldmann and Molas, 1970).

The ultrastructural findings then are not specific, other than being those of cholestasis and cell damage.

The evidence-clinical, light, and electron microscopic-supports a primary hepatocyte injury in benign recurrent cholestasis. In favour of this conclusion are the changes previously mentioned in liver function tests and bromsulphthalein uptake and excretion as well as in the present histopathological changes, normally the doubling of the thickness of the hepatocyte plates, and the non-specific ultrastructural changes.

We wish to thank the Medical Research Council for providing an electron microscope, and Professor $\mathbf{K}$. Weinbren who gave us advice on this work.

\section{References}

Biempica, L., Gutstein, S., and Arias, I. M. (1967). Morphological and biochemical studies of benign recurrent cholestasis. Gastroenterology, 52, 521-535.
Da Silva, L. C., and Brito, T. De (1966). Benign recurrent intrahepatic cholestasis in two brothers: a clinical light and electron microscopic study. Ann. intern. Med., 65, 330-341.

Dickson, E. R., Fletcher, J., and Summerskill, W. H. J. (1965). Ultrastructural changes of the liver in benign recurrent cholestasis. Mayo clin. Proc., 40, 288-295.

Fahrländer, H., Huber, F., and Gloor, F. (1964). Intrahepatic retention of bile in severe bacterial infections. Gastroenterology, 47, 590-599.

Feldmann, G., and Molas, G. (1970). Inclusions cytoplasmiques paracrlstallines dans les hópatocytes chez l'homme. Bull. Ass. Anat., 55, 737-742.

Hug, G., Wong, K. Y., and Lambkin, B. C. (1972). Congenital dyserythropoietic anemia type II. Lab. Invest., 26, 11-21.

Jézéque, A. M. (1959). Dégénérescence myèlinique des mitochondries de foie humain dans un épithélioma du chóledoque et un ictère viral: étude au microscope électronique. J. ultrastruct. Res., 3, 210-215.

Ozsoylu, S., and Kocak, N. (1971). Benign recurrent intrahepatic cholestasis. Clin. Pediat., 10, 123-125.

Pfeifer, U., and Bannasch, P. (1968). Zum Problem der 'hyalinen Eiwesstropfen' im Cytoplasma der Leberparenchymzellen. Lichtund elektronenmikroskopische Untersuchungen nach 3-Hepatektomie. Virchows Arch. Abt. B Zellpath., 1, 365-388.

Popper, H., and Schaffner, F. (1970). Pathophysiology of cholestasis. Hum. Path., 1, 1-24.

Reynolds, E. S. (1963). The use of lead citrate at high pH as an electron opaque stain in electron microscopy. J. Cell Biol., 17, 208-212.

Rotthauwe, H. W., Beseler, W. D., and Kowalewski, S. (1969). Benigne rekurrierende intrahepatische Cholestase. Klin.Wsch)., 47, 140-149.

Sasaki, H., and Schaffner, F., and Popper, H. (1967). Bile ductules in cholestasis: morphologic evidence for secretion and absorption in man. Lab. Invest., 16, 84.

Schaffiner, F., and Popper, H. (1961). Electron microscopic studies of normal and proliferated bile ductules. Amer. J. Path., 38 393-410.

Shiraki, K., and Neustein, H. B. (1971). Intramitochondrial crystalloids and amorphorphous granules. Arch. Path., 91, 32-40.

Spycher, M. A., and Rüttner, J. R. (1968). Kristalloide Einschlüsse in menschlichen Lebermitochondrien. Virchows Arch. Abt. B., 1, 211-221.

Sternlieb, I., Berger, J. E., Biempica, L., Quintana, N., and Hodge, T. (1971). Cytoplasmic crystals in human hepatocytes. Lab. Invest. $25,503-508$.

Summerskill, W. H. J. (1965). The syndrome of benign recurrent cholestasis. Amer. J. Med., 38, 298-305.

Summerskill, W. H. J., and Walshe, J. M. (1959). Benign recurrent intrahepatic "obstructive" jaundice. Lancet, 2, 686-690.

Tanikawa, K. (1968). Ultrastructural Aspects of the Liver and its Disorders. Igaku Shoin, Tokyo. Springer, Berlin.

Watson, M. L. (1958). Staining of tissue sections for electron microscopy with heavy metals. J.biophys. biochem. Cytol., 4, 475-478.

Williams, R., Cartter, M. A., Sherlock, S., Scheuer, P. J., and Hill, K. R. (1964). Idiopathic recurrent cholestasis: a study of the functional and pathological lesions in four cases. Quart. $J$. Med., 33, 387-399. 